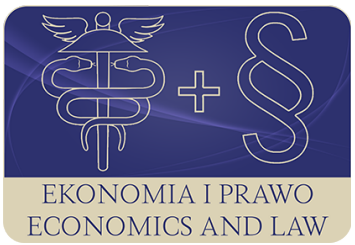

EKONOMIA I PRAWO. ECONOMICS AND LAW

Volume 20, Issue 1, March 2021

p-ISSN 1898-2255, e-ISSN 2392-1625

www.economicsandlaw.pl

ORIGINAL ARTICLE

received 15.09.2021; revised 20.03.2021; accepted 31.03.2021

Citation: Chaikovska, I. (2021). An assessment of bank safety of the Polish listed banks based on the integrated index for bank safety: empirical study. Ekonomia i Prawo. Economics and Law, 20(1):

45-61. doi:10.12775/EiP.2021.003.

\title{
An assessment of bank safety of the Polish listed banks based on the integrated index for bank safety: empirical study
}

\author{
IVANNA CHAIKOVSKA \\ Jagiellonian University in Kraków, Faculty of Management and Social Communication, Institute \\ of Economics, Finance and Management, ul. prof. St. Łojasiewicza 4, 30-348 Kraków, Poland \\ $\square$ ivanna.chaikovska@doctoral.uj.edu.pl \\ (D) orcid.org/0000-0002-9425-2852
}

\begin{abstract}
Motivation: Safety is a key requirement in banking operations. However, it is difficult to maintain and measure through the significant variety and number of the determining factors. No uniform safety measure has been introduced so far that would allow to determine the level of safety and answer the question whether a bank is safe.

Aim: The aim of this paper is to parameterize the bank safety level from the perspective of internal determinants. For this purpose, the author proposes a new synthetic measure - an integrated index for bank safety (IIBS index), which is universal and allows for an assessment of the bank safety level in terms of capital adequacy, liquidity situation, degree of financial leverage and the size of capital buffers. The objective of the empirical study is to measure the safety level of 12 Polish listed banks in 2019 year and differentiate them according to their level of safety.

Results: In the empirical part, an attempt was made to measure the safety level of Polish listed banks in 2019 year. The study covers the 12 Polish listed banks on Bank Focus database and a financial statement review for 2019 year. The analyzed banks were differentiated according to their safety level. Furthermore, the most and the least secure banks were identified, as well as banks that did not meet the minimum regulatory requirements. Results of empirical study, namely the evaluation of bank safety level, will increase the trust the stakeholders have on the banking sector.
\end{abstract}


Keywords: bank safety; regulatory requirements; an integrated index for bank safety; polish listed banks; safety determinants

JEL: G21; G28; G32; K22

\section{Introduction}

Safety is one of the most important condition for the operation of any entity in economic conditions, in particular for banks as institutions of public trust. Ensuring an appropriate level of safety is a key requirement in the operation of banks, which should be achieved by reducing the level of risk and increasing the level of trust from customers and society.

However, ensuring safety is a constant problem for banks due to the specificity of its activities, which is associated with a constant conflict between the need to ensure the safety of the funds held and the desire to maximize the profitability of banking operations. In addition, the intensively changing market conditions, significant links between banking institutions and far-reaching integration in terms of geography (cross-border integration) and sectors (intersectoral integration), lead to a situation in which maintaining safety is a difficult task to achieve.

Due to the significant variety and number of factors determining bank safety, there are difficulties in precisely defining and measuring. On the one hand, bank safety should be observed in terms of its financial condition, and on the other hand - in terms of the environment in which the bank operates. In Polish and foreign literature, there are different approaches to measure a bank safety level, which often take into account single safety determinants, such as level of capital adequacy, liquidity, profitability, leverage, deposit guarantee schemes etc. In these studies, the above-mentioned variables are usually isolated from others and represent only one of many aspects of banking safety. Furthermore, no uniform safety measure has been introduced so far that would allow determining the level of safety and answer the question whether a bank is safe.

According to the above, the aim of this paper is to parameterize the bank safety level from the perspective of internal determinants. For this purpose, the author proposes a new synthetic measure - an integrated index for bank safety (IIBS index), which is universal and allows for an assessment of the bank safety level in terms of capital adequacy, liquidity situation, degree of financial leverage and the size of capital buffers.

Moreover, in accordance with the comparability of data and unambiguous interpretation, the IIBS index is based on the coefficients with standardized formulas developed by the Basel Committee on Banking Supervision. The detailed structure of the IIBS index is presented in the third part of the paper.

Based on an original concept of the IIBS index, in the empirical part, an attempt was made to measure the safety level of Polish listed banks in 2019 year. The analyzed banks were differentiated according to their safety level. Further- 
more, the most and the least secure banks were identified, as well as banks that did not meet the minimum regulatory requirements.

\section{Bank safety determinants: literature review}

In the literature can be found different approaches to defining bank safety. The main reason for the difficulty of uniformly defining safety is the significant variety and number of factors determining bank safety. Bank safety can be defined from various perspectives, namely stability and trust, solvency, risk level, the balance of function execution, level of compliance, banking supervision etc (detail definitions are presented in Table 1). One of the most adequate definition of bank safety is a state in which the bank achieves economic, financial and property equilibrium, which allows it to safely perform its functions even during external shocks (Capiga et al., 2011, p. 67).

Bank safety is one of the most important challenges of the modern economy due to the significant variety and number of determining factors. The bank safety is influenced by both internal factors, e.g. the amount and quality of own funds, the level of reserves and capital buffers or the liquidity situation. As well as external - existing in the environment in which the bank operates (e.g. regulations and supervision, the financial safety net) and indirect, which include the broadly understood market environment (Barth et al., 2002, p. 168). The list of all bank safety determinants is presented in Scheme 1.

Internal factors include the following safety determinants, namely the amount and quality of own funds, liquidity norms, level of reserves and capital buffers, quality of assets, financial leverage. It should be emphasized that for the purposes of this article, the definition of bank safety has been narrowed down to the approach based on internal determinants that directly affect the financial condition of the bank. Selected internal determinants will be discussed in detail below.

The appropriate amount and quality of own funds should reflect the level of risk borne by the bank and the additional surplus that may cover a possible underestimation of risk (Chaikovska, 2020, p. 115). The amount of own funds, in other words, regulatory capital, is determined in accordance with the applicable prudential standards that were introduced by Basel III (BIS, 2010) and then implemented in the EU as part of the CRD IV/CRR (European Council, 2013). These regulations define a detailed methodology for calculating a capital adequacy ratio, which is a measurement of a bank's available capital expressed as a percentage of a bank's risk-weighted credit exposures. It indicates the size of the safety zone for depositors and creditors in the event of unexpected losses (Chaikovska, 2019, p. 41). In order to maintain safety, each bank is obliged to maintain the capital adequacy ratio at the level of $8 \%$, within which the CET1 core capital ratio may not be lower than $4.5 \%$, and the Tier 1 capital ratio - not lower than 6\% (European Council, 2013). The above-mentioned ratios can be 
regarded as one of the basic measures of the bank safety and safety of the entire banking sector.

However, the experience of the last crisis in 2009-2011 has revealed the safety aspects of individual banks, which were underestimated in the pre-crisis period, namely the liquidity situation. In particular, the reported liquidity problems were the first signals of banks' financial problems, before there were problems with solvency. Therefore, in the post-crisis period, quantitative liquidity requirements for banks were introduced for the first time by the Basel Committee on Banking Supervision, which was aimed at improving the safety of banks' operations and increasing their resilience to crisis phenomenon.

Post-crisis quantitative liquidity standards have been implemented by introducing the obligation to use two indicators, namely:

- Liquidity Coverage Ratio - LCR;

- Net Stable Funding Ratio - NSFR.

The LCR ratio refers to the proportion of highly liquid assets held by financial institutions, to ensure their ongoing ability to meet short-term obligations. The target minimum value of this ratio was set at $100 \%$, which was gradually introduced from 2015, and became fully applicable in the European Union in 2018 (European Commission, 2014). The NSFR relates the bank's available stable funding to its required stable funding. The NSFR is expressed as a ratio that must equal or exceed 100\% (BIS, 2018).

Apart from the size and quality of own funds and liquidity, financial leverage plays an important role in building bank safety. The leverage ratio measures a bank's core capital (Tier 1) relative to its total assets. Basel III established a 3\% minimum requirement for the leverage ratio (BIS, 2016). It is important to note that, in accordance with the recommendations of the Polish Financial Supervision Authority regarding the dividend policy, in Poland commercial banks paying out dividends should maintain the financial leverage ratio at a level higher than 5\% (KNF, 2019a).

In the post-crisis period, under the Basel III regulation and the CRD IV / CRR package, capital buffers were also introduced to absorb catastrophic losses, namely (BIS, 2019):

- capital conservation buffer;

- countercyclical capital buffer;

- systemic risk buffer;

- global systemically important institution buffer;

- other systemically important institution buffer.

It is important to note that the capital buffers are part of Common Equity Tier 1 capital, which is a surplus in relation to the capital that meets the capital adequacy ratio. The above-mentioned capital buffer requirements constitute the combined buffer requirement which is mandatory for the European banks. In Poland, the combined buffer requirement is the sum of the buffers in force in 2019 (Act on macroprudential supervision, 2015, Article 55(4)): 
- capital conservation buffer - $2.5 \%$;

- countercyclical capital buffer - 0\%;

- systemic risk buffer - $3 \%^{1}$;

- other systemically important institution buffer - determined by an individual decision of The Polish Financial Supervision Authority.

In order to determine the level of capital buffers can be used own funds surplus/deficit ratio. This ratio is calculated as the difference between the solvency ratio and the capital requirement, which include the combined buffer requirement and min. total capital ratio $8 \%$.

\section{Methods}

In this paper, the author made an attempt to parameterize the level of bank safety from the perspective of selected internal determinants by using quantitative and qualitative methods. In order to measure the level of bank safety, the author proposes the concept of a synthetic measure of safety - an integrated index for bank safety (IIBS index).

In the empirical study, based on an original concept of the IIBS index, an attempt was made to measure the safety level of Polish listed banks in 2019 year. The study covers the 12 Polish listed banks on the Bank Focus database and a financial statement review for 2019 year. During the empirical study, the methods of descriptive and comparative statistics, ratio analysis and analysis of financial statements were used.

\subsection{A theoretical framework and structure of the integrated index for bank safety (IIBS index)}

A theoretical framework of the IIBS index is to measure a bank safety based on 5 internal factors (indicators), namely capital adequacy, short and longterm liquidity indicators, leverage level and own funds surplus/deficit ratio. Above-mentioned indicators have been chosen based on regulatory framework, namely selected internal determinants of bank safety as introduced by Basel III regulatory framework and applied by the EU. This regulatory framework is the core for the methodology of the paper since the suggested IIBS index represents clearly a direct transposition of this regulatory framework into the measure of bank safety.

The structure of the IIBS index is based on the assumption that the financial condition of a bank is determined jointly by capital adequacy, liquidity, leverage and the size of capital buffers ${ }^{2}$. The above aspects of the bank's financial

${ }^{1}$ In connection with the emergence of crisis phenomena related COVID-19 in the Polish banking sector on March 2020, the Minister of Finance signed an ordinance on the repealing of the systemic risk buffer (3\%) (Regulation of the Minister of Finance repealing the regulation on the systemic risk buffer,2020).

2 A similar method is used in an international rating system CAMELS, used by regula- 
condition are subject to post-crisis regulations at the international, European and national level.

The author's construction of index IIBS is based on standardized indicators of banking activity proposed by the Basel Committee on Banking Supervision, namely:

- Capital Adequacy Ratio;

- Liquidity Coverage Ratio - LCR;

- Net Stable Funding Ratio - NSFR;

- Leverage Ratio;

Own Funds Surplus/Deficit Ratio after taking into account the combined buffer requirement and $8 \%$ min. the solvency ratio requirement.

At the same time, it should be emphasized that the Basel Committee for Banking Supervision introduced a uniform methodology for calculating the above ratios and the obligation to meet the minimum capital requirements, liquidity standards, capital buffers and the appropriate degree of financial leverage ${ }^{3}$. This proves the universal nature of the IIBS index and the possibility of using it for comparison purposes.

\subsection{Weighting and aggregation of the integrated index for bank safety (IIBS index)}

This paper uses the equal weighting method of determining the weights of variables, namely all variables are given the same weight (OECD, 2008, p. 31) This essentially implies that all variables are "worth" the same in the IIBS index.

The construction of the IIBS index proposed by the author will enable the parameterization of the bank safety level using the formula:

$$
\begin{aligned}
& \text { Integrated index for bank safety }(\text { IIBS index })= \\
& =\operatorname{avg}\left\{W_{w}, W_{L C R}, W_{\text {NSFR }}, W_{\text {lev }}, W_{\text {sur } / d e f}\right\}
\end{aligned}
$$

where:

$W_{w}$ - rating of value of Capital Adequacy Ratio;

$W_{L C R}$ - rating of value of Liquidity Coverage Ratio;

$W_{\text {NSFR }}$ - rating of value of Net Stable Funding Ratio;

tory banking authorities to analyse bank safety and soundness, according to the six factors represented by its acronym, namely capital adequacy, asset quality, management, earnings, liquidity, and sensitivity (FED, 2019, p. 4).

3 The only exception is the Own Funds Surplus/Deficit Ratio. This ratio is calculated as the difference between the capital adequacy ratio and the capital requirement, which include combined buffer requirement and min. capital adequacy ratio $8 \%$

${ }^{4}$ Numerous methods have been suggested in the literature to determine the weights of diagnostic variables, e.g. equal weighting, expert method, principal components analysis, "benefit of the doubt", unobserved components model, budget allocation process, based on coefficients of variation or correlation coefficients etc. (OECD, 2008, p. 31). 
$W_{\text {lev }}$ - rating of value of Leverage Ratio;

$W_{\text {surddef }}$ - rating of value Own Funds Surplus/Deficit Ratio.

Important to note, the proposed formula for determining the bank safety level using the IIBS index is the arithmetic average of the ratings of the values presented above. The arithmetic average of the ratings is a measure of central tendency, which informs about the average level of bank safety, without reflecting the differences between analyzed individual indicators. Autor assign IIBS index's components ratings on a scale of "l" to "4". A rating of " 1 " indicates the highest rating and the strongest bank safety in terms of individual indicator. On the other hand, a rating of " 4 " indicates the lowest rating and the weakest bank safety in terms of an individual indicator.

\subsection{The assumptions of the ratings of the integrated index for bank safety (IIBS index)}

In reference to the above, it is also necessary to establish threshold values that will indicate the appropriate level of bank safety. In relation to this, in order to interpret the results of the IIBS index and differentiate the assessed banks, the author proposes to distinguish 4 levels of safety ${ }^{5}$. A detailed description of the ratings of the IIBS indexes and safety levels is presented in Table 2.

The lowest rating of the IIBS index is the 4th rating, which reflects the insufficient level of the bank safety. It has been determined on the basis of the Basel minimum regulatory requirements, namely capital adequacy ratio not lower than $8 \%$, the LCR ratio - $100 \%$, the NSFR ratio - 100\%, and the leverage ratio $-3 \%$ (Table 2). Moreover, the own funds surplus/deficit ratio should be greater than 0 (level of own funds can cover the $8 \%$ minimum capital requirement and the combined buffer requirement). For instance, in 2019 year in Poland, the combined buffer requirement was at the minimum level of 5.5\% and was increased for some Polish banks by the value of the buffer of other systemically important institutions based on an individual decision of the Polish Financial Supervision Authority (KNF, 2019b). Failure to meet the minimum regulatory requirements will result in assigning the appropriate ratios the value of 4 .

The next is the 3rd rating, which determines the bank's sufficient level of safety and partially reflected the level of ratios recommended by national supervisors. For instance, in 2019 year in Poland it was recommended to maintain the capital adequacy ratio at a level not lower than the required minimum increased by $1.5 \%$, i.e. $17 \%{ }^{6}$. Further to this, rating 3 for the capital adequacy ratio was defined from $8 \%$ to $17 \%$.

\footnotetext{
5 A similar method was proposed by Koleśnik (2011, p. 106).

${ }^{6} 8 \%+$ add-on (an additional capital requirement to cover the risk related to foreign currency loans, imposed as part of individual decisions on banks ( $2 \%$ on average, depending on the bank, it amounted to $0.4 \%$ to $6.4 \%$ ) under Pillar II ) + the combined buffer requirement $(5.5-6.5 \%)+1.5 \%$.
} 
According to Table 2, in order to determine the 3rd rating for the remaining ratios, were used the average values of the Polish commercial banking sector in 2015-2019 years. Which respectively accounted for the LCR - 146\%, the NSFR - 120\%, the leverage ratio - 7.30\% (KNF, 2020, p. 63). On this basis, the values of ratios below the average were assigned to the rating 3 . In addition, it was specified that in the 3rd rating, the value of own funds surplus/ deficit ratio should be at the level of $2.75 \%$ (the average value of the systemic risk buffer 3\% and the countercyclical buffer 2.5\% - not applicable in the Polish banking sector) (KNF, 2020, p. 16).

Correspondingly, the 2nd rating, which determines the bank's good level of safety, has been assigned the values of LCR, NSFR and leverage above the average level (Table 2). In the 2nd rating, the value of the own funds surplus/deficit ratio was set within $2.75-5 \%$, and the capital adequacy ratio withinl7-18.25\% (where the upper limit is the average value of the capital adequacy index of the Polish banking sector in 2015-2019 years) (KNF, 2020, p. 64). During the calculation of the IIBS index for ratios within the above intervals will be assigned a value equal to 2 .

The highest level of safety is characterized by a lst rating. This rating includes values above $18.25 \%$ for the capital adequacy ratio, $160 \%$ - for LCR, $130 \%$ for NSFR, $10 \%$ - for leverage ratio and 5\% for own funds surplus/deficit ratio. Pinning the value to $l$ in this rating means that the bank is secure in terms of capital adequacy, liquidity situation, degree of financial leverage and the size of capital buffers.

As indicated in Table 2, for example, a bank with a capital adequacy ratio of $17 \%$, LCR - $161 \%$, NSFR - $117 \%$, leverage ratio - 9.3\% and own funds surplus/deficit ratio $-2.85 \%$, would have received a 2 nd degree of safety since his IIBS index would be 2 (avg $\{2,1,3,2,2\})$. This means that the bank safety level could be assessed as good.

\subsection{Interpretation of an integrated index for bank safety (IIBS index)}

Interpretation of the results of the IIBS index analysis consists in the following:

- if the IIBS index is between 1 and 1.5 - it proves the high level of bank safety. In other words, the bank has sufficient own funds to cover both expected and unexpected losses as well as catastrophic losses ${ }^{7}$. During both the upward and downward phases of the business cycle, the bank achieves economic, financial and property equilibrium, which allows it to safely perform its functions even during external shocks.

- if the IIBS index is between 1.6 and 2.5 - it proves the good level of bank safety. In this situation, the bank performs its functions, comply with appli-

7 Catastrophic losses occur under stress conditions, i.e. those that are very unlikely but possible (e.g. systemic risk). These losses can cause bank insolvency and should be covered by capital buffers, namely conservation, countercyclical and systemic risk buffers. 
cable regulations, and available to absorb various types of losses. The values of the analyzed ratios are close to the average of the banking sector. The bank safety level depends on the situation of the entire banking sector and may be damaged in the event of systemic risk or crisis phenomena.

- if the IIBS index is between 2.6 and 3 - it proves the sufficient level of bank safety. In this situation, the bank is able to absorb expected and partially unexpected losses. At the same time, it should be emphasized that there is a risk of underestimating the amount of losses due to the omission of certain types of risk (e.g. systemic risk during the financial crisis 2009-2011 years), which in an extreme scenario may lead to bank bankruptcy. In addition, a bank may be insecure in one or more of the analyzed aspects due to non-compliance with the minimum requirements for capital adequacy, liquidity, financial leverage or the size of capital buffers. This means that, as a result of unfavourable phenomena in the banking sector, there is a high probability that the bank will lose its solvency and/or liquidity, which may lead to bankruptcy and lower safety of the entire banking sector.

- if the IIBS index is between 3.1 and 4 - it proves the insufficient level of bank safety. In particular, one or more of the analyzed indicators is below the required minimum level, i.e. the bank is insecure in one aspect capital adequacy, liquidity, leverage or the amount of capital buffers. If the IIBS index is equal to 4, then there is a lack of safety in all of the above-mentioned aspects. The mismanagement of a bank with an insufficient level of safety may lead to bankruptcy, loss of capital by shareholders and deposits by depositors, which may contribute to the safety failure of the entire banking sector.

Summarizing the above-indicated, firstly, the assumptions of the IIBS index presented above will make possible to measure the level of safety of individual banks, and then differentiate them and compare. The application of the IIBS index proposed by the author can be used to banks from one or different countries.

In addition, the advantage of the proposed IIBS index is that it takes into account the values of ratios that banks are required to disclose in their financial statements under Pillar III of the CRR ${ }^{8}$. Furthermore, transparency has a positive impact on the safety of the bank and the entire banking sector.

\section{Results}

Based on an original concept of IIBS index an attempt was made to measure the safety level of 12 Polish listed banks in 2019 year, namely:

- Powszechna Kasa Oszczędności Bank Polski S.A. (PKO Bank);

- Santander Bank Polska S.A. (Santander Bank);

8 According to the Regulation 2019/876 of the European Parliament and of the Council (2019) of 20 May 2019, amending Regulation 575/2013 and Regulation 648/2012 on the publication of information about the values of the NSFR will be obligatory only for banks after June 28, 2021. 
- Bank Polska Kasa Opieki S.A. (Pekao Bank);

- ING Bank Śląski S.A. (ING Bank);

- mBank S.A. (mBank);

- BNP Paribas Bank Polska S.A. (BNP Paribas);

- Bank Handlowy w Warszawie S.A. (Bank Handlowy w Warszawie);

- Bank Millennium S.A. (Millennium Bank);

- Alior Bank S.A. (Alior Bank);

- Getin Noble Bank S.A. (Getin Noble Bank);

- Bank Ochnony Środowisko S.A. (Bank Ochrony Środowiska);

- Idea Bank S.A. (Idea Bank).

The empirical study used data from the Bank Focus database and the annual financial statements of the analyzed banks in 2019 year. This made possible to obtain the source data for the calculation of the IIBS index, which is presented in Table 3. In addition, the author used the annual reports and announcements of the Polish Financial Supervision Authority to determine the requirement of a combined buffer taking into account the value of the buffer of other systemically important institutions, determined by an individual decision. Based on the above, the author calculated the Own Funds Surplus/Deficit Ratio as the difference between the value of the capital adequacy ratio and the combined buffer requirement and the $8 \%$ minimum level of the capital adequacy ratio.

In order to calculate the value of the IIBS index, each ratio of a particular bank has been assigned the appropriate rating from Table 4. For example, for Bank Handlowy w Warszawie rating 2 was assigned for the capital adequacy ratio - $17.2 \%$, rating 1 for the LCR ratio - $169.8 \%$, rating 3 for the NSFR ratio $-100 \%$, and rating 2 for the leverage ratio $-8.9 \%$ and own funds surplus/ deficit ratio - $3.45 \%$. Based on this, the IIBS index was calculated as the arithmetic average of $\{2,1,3,2,2\}$, and its value was 2 . This means that in 2019 Bank Handlowy w Warszawie received the second level of safety, in other words safety this bank was rated as good. The assigned ratings of the ratios for the analyzed banks and the IIBS index values are presented in Table 4.

Table 4 shows that among the 12 analyzed banks, Bank Millenium (1.2), mBank (1.4) and Santander Bank (1.4) received the highest value of the IIBS index. Taking into account that the IIBS index value of these banks is in the rating of 1-1.5, it should be stated that the level of safety of Bank Millennium, mBank and Santander Bank is high. This means that these banks can safely perform their functions even during external shocks. In particular, in 2019 year Bank Millennium had the highest level of safety among Polish listed banks, by maintaining the analyzed ratios at a high level. Comparing the situation of mBank and Santander bank, it should be stated that mBank is safer in terms of capital adequacy and the level of capital buffers, and Santander Bank - in terms of long-term liquidity (NSFR) and the degree of leverage.

There is a group of banks with the value of the IIBS index between 1.6-2.5, namely PKO Bank (1.6), Bank Handlowy in Warsaw (2), Pekao Bank (2), Alior Bank (2.2), Bank Ochrony Środowiska (2.4) and BNP Paribas Bank (2.4). 
The level of safety of these banks should be assessed as good by meeting all the minimum regulatory requirements. Moreover, it should be emphasized that the values of the analyzed ratios of these banks are similar to the average of the sector, which means that these banks shaped the level of safety of the banking sector in Poland in 2019 year. This group includes PKO Bank (1.6), the level of safety of which is very close to high. Reverse trends can be observed in the case of the Bank Ochrony Środowiska (2.4) and BNP Paribas Bank (2.4), which are located on the border between good and sufficient level of safety.

The next group is a group of banks with a sufficient level of safety, which include ING Bank (2.6) Getin Noble Bank (2.8) and ideas Bank (3.0). These banks have the ability to absorb expected and partly unexpected losses. At the same time, these banks are exposed to the risk of underestimating the amount of losses due to the omission of certain types of risk (e.g. COVID-19 pandemic risk), which is an extreme scenario that may lead to bank bankruptcy. It should be distinguished Getin Noble Bank and Idea Bank, which failed to meet some minimum regulatory requirements and were assigned to the 4 th rating of values (Table 4). In particular, Getin Noble Bank in 2019 year was characterized by a deficit of own funds by $3.5 \%$, which proves the inability to meet the $8 \%$ capital adequacy ratio and the combined buffer requirement. Therefore, Getin Noble Bank's integrated safety level has been lowered by the own funds surplus/deficit ratio.

The lowest level of safety among the analyzed banks was characteristic of Idea Bank, which in 2019 year did not meet the appropriate minimum for the capital adequacy ratio, the leverage ratio and own funds surplus/deficit ratio. So, Idea Bank in 2019 year was characterized by unsafety in terms of solvency and the degree of financial leverage, which made it the subject of corrective supervisory actions by the Polish Financial Supervision Authority. At the same time, Idea Bank maintained one of the highest levels of the short-term and long-term liquidity ratio, which resulted that the integrated level of safety has developed at a sufficient level, however, which is very close to insufficient ${ }^{9}$. It should be emphasized that improper management of a bank with a border safety level to insufficient may lead to its bankruptcy, loss of capital by shareholders and deposits by depositors, and then - to undermine the safety of the entire banking sector.

\section{Conclusion}

In this paper, the bank safety level has been parameterized by using the proprietary concept of an integrated index for bank safety (IIBS index). IIBS index is a new synthetic measure of bank safety level, which is universal and allows for an assessment of the bank safety level in terms of capital adequacy, liquidity

9 At the same time, it should be considered whether the IIBS index should be restrictive and prevent a bank from obtaining a grade other than the worst, at least one of the ratios of which does not meet the minimum appropriate for it. 
situation, degree of financial leverage and the size of capital buffers. Moreover, the IIBS index is based on the coefficients with standardized formulas developed by the Basel Committee on Banking Supervision.

In the empirical part, the safety level of Polish listed banks in 2019 year was analyzed based on the IIBS index. 12 Polish listed banks were appropriately differentiated in terms of the level of safety in 2019 year (Table 4). In 2019 year, the three most secure banks were Bank Millennium (1.2), mBank (1.4) and Santander Bank (1.4), and the three least secure - ING Bank (2.6), Getin Noble Bank (2.8) and Idea Bank (3). It is important to note, that Idea Bank in 2019 year was characterized by a lack of safety in terms of capital adequacy, the amount of capital buffers and the degree of financial leverage. In relation to this, it is important in Poland to strengthen the safety of Idea Bank in order to maintain a high level of safety of the entire banking sector.

\section{References}

Alior Bank. (2020). Raport skonsolidowany 2019. Retrieved 04.03.2021 from https: / /www.aliorbank.pl.

Bank Handlowy w Warszawie. (2020). Wyniki skonsolidowane IV kw. 2019 r. Retrieved 04.03.2021 from https://www.citibank.pl.

Bank Millenium. (2020). Skonsolidowany raport roczny Grupy Banku Millennium za rok 2019. Retrieved 04.03.2021 from https://www.bankmillennium.pl.

Bank Ochrony Środowiska. (2020). Roczne skonsolidowane sprawozdanie finansowe Grupy Kapitatowej Banku Ochrony Środowiska SA za rok zakończony dnia 31 grudnia 2019 roku wraz ze sprawozdaniem z badania niezależnego biegtego rewidenta. Retrieved 04.03.2021 from https://www.bosbank.pl.

Barth, J., Dopico, L., Nolle, D., \& Wilcox, J. (2002). Bank safety and soundness and the structure of bank supervision: a cross-country analysis. International Review of Finance, 3(3/4). doi:10.1111/j.1369-412x.2002.00037.x.

BIS. (2010). Basel III: a global regulatory framework for more resilient banks and banking systems. Retrieved 20.08.2020 from http://www.bis.org.

BIS. (2016). Revisions to the Basel III leverage ratioframework. Retrieved 19.08.2020 from https://www.bis.org.

BIS. (2018). Net stable funding ratio (NSFR): executive summary. Retrieved 20.08.2020 from https://www.bis.org.

BIS. (2019). The capital buffers in Basel III: executive summary. Retrieved 26.08.2020 from https://www.bis.org.

BNP Paribas Bank. (2020). Skonsolidowane sprawozdanie finansowe Grupy Kapitatowej BNP Paribas Bank Polska SA za rok zakończony dnia 31 grudnia 2019 roku. Retrieved 04.03.2021 from https://www.bnpparibas.pl.

Capiga, M., Gradoń, W., \& Szustak, G. (2011). Adekwatność kapitatowa w ocenie bezpieczeństwa banku. Warszawa: CeDeWu. 
Chaikovska, I. (2019). Zasada zapewnienia zgodności a działania dyscyplinujące organów nadzoru bankowego w okresie pokryzysowym. Bezpieczny Bank, 3(76). doi:10.26354/bb.2.3.76.2019.

Chaikovska, I. (2020). Determinanty bezpieczeństwa sektora bankowego w Unii Europejskiej. In M. Sosnowski (Ed.), Problemy finansów w obliczu przemian rozwojowych i niepewności. Wrocław: Uniwerstet Ekonomiczny we Wrocławiu.

Daniluk, D. (1997). Bezpieczeństwo systemu bankowego w Unii Europejskiej i w Polsce. In B. Pietrzak (Ed.), Euro a strategie polskich banków. Warszawa: Twigger.

European Commission. (2014). Liquidity coverage requirement delegated act: frequently asked questions. Retrieved 21.08.2020 from https://ec.europa.eu.

European Council. (2013). Capital requirements for the banking sector. Retrieved 18.08.2020 from https://www.consilium.europa.eu.

FED. (2019). FDIC and Federal Reserve request information on use and impact of CAMELS ratings. Retrieved 04.04.2021 from https://www.federalreserve.gov.

Getin Noble Bank. (2020). Raport skonsolidowany za 2019r. Retrieved 04.03.2021 from https://www.gnb.pl.

Hughes, J.P., Lang, W., Mester, L.J., \& Moon, C.-C.. (1996). Safety in numbers: geographic diversification and bank insolvency risk. Federal Reserve Bank of Philadelphia Working Papers, 96-14.

Idea Bank. (2020). Skonsolidowane sprawozdanie finansowe za rok zakończony dnia 31.12.2019. Retrieved 04.03.2021 from https://www.relacje.ideabank.pl.

ING Bank. (2020). Roczne skonsolidowane sprawozdanie finansowe za 2019 rok. Retrieved 04.03.2021 from https://www.ing.pl.

Iwanicz-Drozdowska, M. (2000). Determinanty bezpieczeństwa banków w świetle analizy wybranych kryzysów bankowych. Warszawa: SGH.

Kaufman, G.G., Benston, G.J., Eisenbeis, R.A., Horvitz, R.A., \& Kane, E.J. (1986). Perspectives on safe and sound banking. Cambridge: MIT Press.

KNF. (2019a). Komunikat KNF dotyczący stanowiska organu nadzoru w sprawie zatożeń polityki dywidendowej banków komercyjnych, banków spótdzielczych i zrzeszających oraz zakładów ubezpieczeń i reasekuracji w 2020 r. Retrieved 25.08.2020 from https://www.knf.gov.pl.

KNF. (2019b). Przegląd adekwatności wskaźnika bufora innej instytucji o znaczeniu systemowym. Retrieved 25.08.2020 from https://www.knf.gov.pl.

KNF. (2020). Informacja na temat sektora bankowego. Retrieved 15.08.2020 from https://www.knf.gov.pl.

Koleśnik, J. (2011). Bezpieczeństwo systemu bankowego: teoria i praktyka. Warszawa: Difin.

mBank. (2020). Raport zintegrowany 2019. Retrieved 04.03.2021 from https:// www.mbank.pl.

Moody's Analytics BankFocus. (2020). Retrieved 15.08.2020 from https:// www.bvdinfo.com. 
OECD. (2008). Handbook on constructing composite indicators: methodology and user guide. Retrieved 26.08.2020 from https://www.oecd.org.

Pekao Bank. (2020). Skonsolidowane sprawozdanie finansowe Grupy Kapitatowej Banku Pekao SA za 2019 r. Retrieved 04.03.2021 from https://www.pekao. com.pl.

PKO Bank. (2020). Skonsolidowane sprawozdanie finansowe Grupy Kapitatowej PKO Banku Polskiego SA za rok zakończony 31 grudnia 2019 roku. Retrieved 04.03.2021 from https://www.pkobp.pl.

Regulation (EU) 2019/876 of the European Parliament and of the Council of 20 May 2019 amending Regulation (EU) No 575/2013 as regards the leverage ratio, the net stable funding ratio, requirements for own funds and eligible liabilities, counterparty credit risk, market risk, exposures to central counterparties, exposures to collective investment undertakings, large exposures, reporting and disclosure requirements, and Regulation (EU) No 648/2012 (OJ L 150, 7.6.2019).

Rozporządzenie Ministra Finansów z dnia 18 marca 2020 r. uchylające rozporządzenie $\mathrm{w}$ sprawie bufora ryzyka systemowego [Regulation of the Minister of Finance of March 18, 2020 repealing the regulation on the systemic risk buffer] (Dz.U. 2020 poz. 473) (Poland).

Santander Bank. (2020). Raport roczny Grupy Kapitatowej Santander Bank Polska SA za 2019 rok. Retrieved 04.03.2021 from https://www.santander.pl.

Torp, J. (2007). Bank safety and soundness regulatory service. New Providence: LexisNexis.

Ustawa z dnia 5 sierpnia 2015 r. o nadzorze makroostrożnościowym nad systemem finansowym i zarządzaniu kryzysowym w systemie finansowym [Act of August 5, 2015 on macroprudential supervision over the financial system and crisis management in the financial system] (Dz.U. 2015 poz. 1513) (Poland).

Vauhkonen, J. (2009). Bank safety under Basel II capital requirements. Bank of Finland Research Discussion Papers, 29.

Vauhkonen, J. (2012). The impact of pillar 3 disclosure requirements on bank safety. Journal of Financial Services Research, 41. doi:10.1007/ s10693-011-0107-X.

\section{Acknowledgements}

Author contributions: author has given an approval to the final version of the article.

Funding: this research was undertaken as part of the Visegrad Scholarship Program and was fully funded by a grant (52011200).

Note: the results of this study were presented at 9th Scientific Conference: Contemporary Economic Problems 'Thirty years of transformation' (September, 16, 2020, online, Poland). 


\section{Appendix}

Table 1.

Review of the definition of bank safety

Definition of bank safety

Bank safety as a state in which the bank achieves economic, financial and property balance, which allows it to safely perform its functions even in the event of periodic external shocks (Capiga et al., 2011, p. 67).

Bank safety relates to the risk of default (Hughes et al., 1996, p. 31).

Safety used to mean things you did to avoid bank failure (Torp, 2007, p. 28).

A bank safety is synonymous with its solvency, which occurs when the market value of the bank's assets exceeds the value of its liabilities (Iwanicz-Drozdowska, 2000, p. 271).

Bank safety means a state in which the bank, having achieved equilibrium, fulfills its functions for the benefit of the economy and its clients, maintaining the ability to develop and absorb external shocks (Daniluk, 1997, p. 90).

The safety of banks is defined through the prism of stakeholder trust (Koleśnik, 2011, pp. 54-55).

Regulator can improve the safety of the banking system by tightening the disclosure requirements (Vauhkonen, 2012, p. 47).

A fundamental requirement for maintaining the safety of the banking sector is to ensure compliance of banking activities with the applicable regulatory requirements (Kaufman et al., 1986, p. 18).

The transparency of the activities has a positive impact on bank safety through disclosure of information on risk profile, capital adequacy and risk assessment processes (Vauhkonen, 2009, p. 7).

Source: Own preparation.

Table 2.

Description of the ratings of the IIBS index and levels of safety proposed by the author (\%)

\begin{tabular}{lcccccc}
\hline \multirow{2}{*}{$\begin{array}{c}\text { Bank safety } \\
\text { level }\end{array}$} & Rating & $\begin{array}{c}\text { Capital } \\
\text { adequacy ratio }\end{array}$ & LCR & NSFR & Leverage ratio & $\begin{array}{c}\text { Own funds } \\
\text { surplus/deficit ratio }\end{array}$ \\
\cline { 2 - 6 } & $W_{w}$ & $W_{\text {LCR }}$ & $W_{\text {NSFR }}$ & $W_{\text {lev }}$ & $W_{\text {surdef }}$ \\
\hline high & 1 & $>=18.25$ & $>=160$ & $>=130$ & $>=10$ & $>=5$ \\
good & 2 & {$[17 ; 18.25)$} & {$[146 ; 160)$} & {$[120 ; 130)$} & {$[7.30 ; 10)$} & {$[2.75 ; 5)$} \\
sufficient & 3 & {$[8 ; 17)$} & {$[100 ; 146)$} & {$[100 ; 120)$} & {$[3 ; 7.30) \%$} & {$[0 ; 2.75)$} \\
insufficient & 4 & $<8$ & $<100$ & $<100$ & $<3$ & $<0$ \\
\hline
\end{tabular}

Source: Own preparation. 
Table 3.

The value of ratios included in the IIBS index of 12 Polish listed banks in 2019 (\%)

\begin{tabular}{lrrrrr}
\hline \multicolumn{1}{c}{ Bank name } & $W_{w}$ & $W_{\text {LCR }}$ & $W_{\text {NSFR }}$ & $W_{\text {lev }}$ & $W_{\text {sur def }}$ \\
\hline Bank Millennium & 20.09 & 171 & 135 & 8.11 & 6.59 \\
mBank & 19.46 & 169 & 127 & 8.25 & 5.21 \\
Santander Bank & 17.07 & 171 & 130 & 10.05 & 2.82 \\
PKO Bank & 18.42 & 146 & 123 & 10.07 & 3.92 \\
Bank Handlowy w Warszawie & 17.2 & 170 & $100^{*}$ & 8.90 & 3.45 \\
Pekao Bank & 17.1 & 152 & 127 & 9.30 & 2.85 \\
Alior Bank & 16.2 & 148 & 130 & 8.34 & 2.70 \\
Bank Ochrony Środowiska & 16.39 & 131 & 109 & 10.40 & 2.89 \\
BNP Paribas Bank & 15.03 & 162 & $100^{*}$ & 8.80 & 1.28 \\
ING Bank & 16.87 & 130 & 130 & 7.23 & 2.62 \\
Getin Noble Bank & 10.00 & 163 & $100^{*}$ & 5.80 & -3.50 \\
Idea Bank & 1.46 & 156 & 142 & 0.40 & -12.04 \\
\hline
\end{tabular}

* maintaining the NSFR ratio above the required level $100 \%$ - entry in the financial statements of Bank Handlowy w Warszawie, BNP Paribas Bank and Getin Noble Bank.

Source: Own preparation based on: Alior Bank (2020); Bank Handlowy w Warszawie (2020); Bank Millenium (2020); Bank Ochrony Środowiska (2020); BNP Paribas Bank (2020); Getin Noble Bank (2020); Idea Bank (2020); ING Bank (2020); mBank (2020); Moody's Analytics BankFocus (2020); Pekao Bank (2020); PKO Bank (2020); Santander (2020).

Table 4.

Assigned ratings of the ratios values included in the IIBS index and the value of the IIBS index for 12 Polish listed banks in 2019

\begin{tabular}{lrrrrrrrrrrr}
\hline \multicolumn{1}{c}{ Bank name } & $W_{w}$ & $\mathrm{Pl}$ & $W_{\text {LCR }}$ & $\mathrm{P} 2$ & $W_{\text {NSFR }}$ & $\mathrm{P} 3$ & $W_{\text {lev }}$ & $\mathrm{P} 4$ & $W_{\text {sur/def }}$ & P5 & $\begin{array}{c}\text { Index } \\
\text { IIBS }\end{array}$ \\
\hline Bank Millennium & 20.09 & 1 & 171 & 1 & 135 & 1 & 8.11 & 2 & 6.59 & 1 & 1.2 \\
mBank & 19.46 & 1 & 169 & 1 & 127 & 2 & 8.25 & 2 & 5.21 & 1 & 1.4 \\
Santander Bank & 17.07 & 2 & 171 & 1 & 130 & 1 & 10.05 & 1 & 2.82 & 2 & 1.4 \\
PKO Bank & 18.42 & 1 & 146 & 2 & 123 & 2 & 10.07 & 1 & 3.92 & 2 & 1.6 \\
Bank Handlowy w Warszawie & 17.2 & 2 & 170 & 1 & $100^{*}$ & 3 & 8.90 & 2 & 3.45 & 2 & 2.0 \\
Pekao Bank & 17.1 & 2 & 152 & 2 & 127 & 2 & 9.30 & 2 & 2.85 & 2 & 2.0 \\
Alior Bank & 16.2 & 3 & 148 & 2 & 130 & 1 & 8.34 & 2 & 2.70 & 3 & 2.2 \\
Bank Ochrony Środowiska & 16.39 & 3 & 131 & 3 & 109 & 3 & 10.40 & 1 & 2.89 & 2 & 2.4 \\
BNP Paribas Bank & 15.03 & 3 & 162 & 1 & $100^{*}$ & 3 & 8.80 & 2 & 1.28 & 3 & 2.4 \\
ING Bank & 16.87 & 3 & 130 & 3 & 130 & 1 & 7.23 & 3 & 2.62 & 3 & 2.6 \\
Getin Noble Bank & 10.00 & 3 & 163 & 1 & $100^{*}$ & 3 & 5.80 & 3 & -3.50 & 4 & 2.8 \\
Idea Bank & 1.46 & 4 & 156 & 2 & 142 & 1 & 0.40 & 4 & -12.04 & 4 & 3.0 \\
\hline
\end{tabular}

* maintaining the NSFR ratio above the required level $100 \%$ - entry in the financial statements of Bank Handlowy w Warszawie, BNP Paribas Bank and Getin Noble Bank.

Source: Own preparation based on: Alior Bank (2020); Bank Handlowy w Warszawie (2020); Bank Millenium (2020); Bank Ochrony Środowiska (2020); BNP Paribas Bank (2020); Getin Noble Bank (2020); Idea Bank (2020); ING Bank (2020); mBank (2020); Moody's Analytics BankFocus (2020); Pekao Bank (2020); PKO Bank (2020); Santander (2020). 


\section{Scheme 1.}

Bank safety determinants

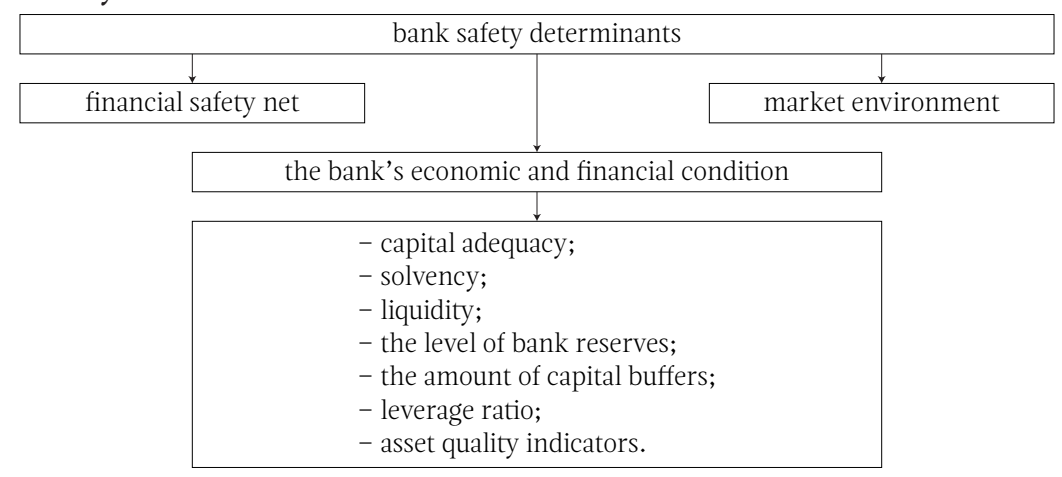

Source: Own preparation. 
